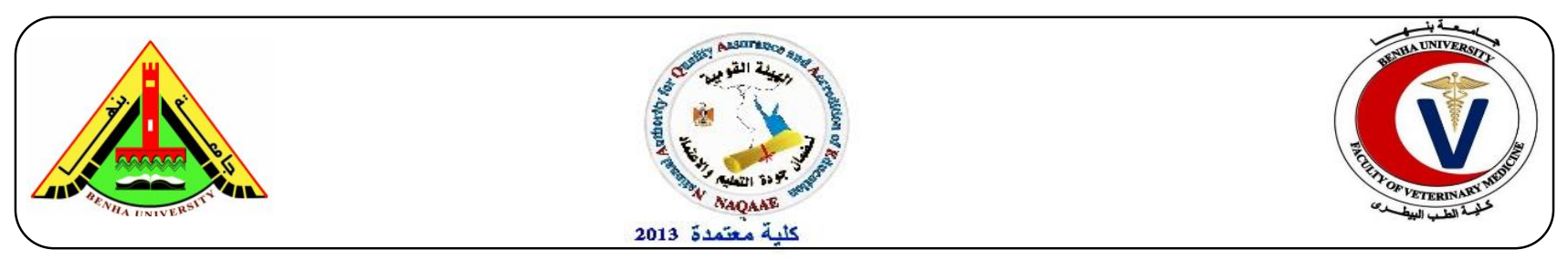

\title{
In vivo cloning of plasmids in $E$. coli is a simpler and faster method for cloning
}

Osama Ahmed ${ }^{1,2}$, Mohamed Attia ${ }^{1}$, Hatem Bahgat $^{1}$, Ahmed Kassab ${ }^{1}$, Masatake Osawa ${ }^{2}$, Md Nojebuzzaman ${ }^{2}$

${ }^{1}$ Department of Anatomy \& Embryology, Faculty of Veterinary Medicine, Benha University, Moshtohor, Toukh 13736, Egypt.

${ }^{2}$ Laboratory of Molecular design and Synthesis, Department of Regenerative Medicine and Applied Medical Science, Gifu University, 1-1 Yanagido, Gifu 501-1194, Japan.

\section{A B S T R A C T}

DNA assembly sequences into plasmids is one of the most important basic technologies for bioscience research and metabolic engineering. There are many of molecular cloning techniques have been developed and these techniques that need specialized expensive reagents or laborious experimental procedure. For that reason, a significant amount of effort has been dedicated to developing better DNA assembly methods with higher efficiency and fidelity as well as simpler and faster protocols. Here, we compared between conventional, in vivo and in vitro DNA assembly methods and their recent applications, we also highlight the optimum protocol for in vivo cloning of DNA assembly methods. The present study concluded that vector construction can be carried out simply by simply placing a DNA fragment having a homologous sequence and directly transformed into E. coli and this method gives great help in improving efficiency of molecular biological research.

Keywords: in vivo cloning, PCR, conventional cloning, transformation and invitro cloning.

(http://www.bvmj.bu.edu.eg)

(BVMJ-35(2): 219-230, 2018)

\section{INTRODUCTION}

The progress of recombinant DNA techniques has greatly increased our ability to manipulate DNA for the purpose of gene alteration, fusion protein construction, DNA and protein library generation, metabolic pathway assembly, and synthetic chromosome and genome construction (Gibson et al. 2008 $\&$ Shao and Zhao, 2014) Conventional cloning techniques (Cohen et al. 1973\& Lobban and Kaiser 1973) depend on restriction enzyme digestion and DNA ligation, require multiple tough steps of DNA manipulation involving enzymatic reactions and DNA purification, and have relatively low cloning efficiencies.
The requirement for restriction sites puts a severe stress on the DNA sequence, especially for relatively large plasmids where unique restriction sites at desired locations are difficult to find. To overcome these limitations, many sequence- and ligationindependent cloning methods have been developed. These methods, such as SLIC (Li \& Elledge, 2007), Ligation-independent cloning (LIC)-PCR (Aslanidis \&Jong, 1990), In-fusion (Zhu et al., 2007); USER (Geu-Flores et al., 2007) and Gibson Assembly (Gibson et al., 2009) need overlapping ends of DNA fragments and are proceeded by the creation of 
overhangs through either 3'\&5' exonuclease activity followed by complementary strand annealing and DNA gap-filling by a DNA polymerase. Furthermore, DNA may be joined together by a DNA ligase. While these methods are efficient in assembling multiple DNA fragments but need expensive reagents and further steps following DNA fragment preparation.

An invivo recombination principle was first established in E. coli with DNA fragments acquiring homologous sequences more than 3 decades ago (Watt et al. 1985). Nevertheless, its simplicity, the invivo recombination principle has not been widely used for general cloning purposes. Its lack of broad acceptance may be due to its relatively low efficiency and little understanding of quantitative interactions among cloning efficiency. The high recombination efficiency depends on the length of overlapping DNA sequences, the number of DNA fragments and the size of plasmids.

Since then, cloning based on invivo recombination has been cultivated in yeast (Ma et al., 1987; Oldenburg et al., 1997; Joska et al., 2014 and van Leeuwen et al., 2015) and E. coli (Bubeck et al. 1993, Oliner et al. 1993). Even E. coli strains with Red/RecET recombinases are good hosts for invivo cloning (Muyrers et al. 2000, Zhang et al. 2000, Trehan et al. 2016 and Li et al. 2011) also derivatives of the commonly used DH5 $\alpha$ lab strain without recA and Red/RecET activities can be used successfully for invivo assembly of plasmids (Lovett et al., 2002; Cao et al., 2014; Jacobus\& Gross, 2015; Kostylev et al., 2015 and GarciaNafria et al., 2016).

Unlike conventional cloning and SLIC methods, invivo recombination cloning need only DNA fragments with overlapping ends, which can be prepared by PCR to eliminate the need for additional enzymes such as exonuclease and DNA ligase for DNA manipulation. However, the simplicity of invivo cloning principle is starting to increase the attention of researchers and focus on improving the practical aspects of invivo cloning to make it simple, fast, and efficient compared with other cloning techniques ( $\mathrm{Li}$ et al., 2011 and Jacobus\& Gross, 2015 and Kostylev et al., 2015)

A recent report explained that preparation of multiple DNA fragments with overlapping ends in a single-tube PCR reaction (Oliner et al., 1993) and also need DpnI digestion of PCR products to remove template plasmids before transformation to reduce colony background. Although, the exact mechanism is still unknown (Bubeck et al., 1993), the nonconventional recA-independent recombination activity need homologous DNA sequences and is enhanced by the absence of the recA protein and exonucleases (Lovett et al., 2002 and Dutra et al., 2007).

The invivo cloning method may be performed to construct plasmids up to $16 \mathrm{~kb}$ within 2 days (Huang et al., 2017), All DNA fragments prepared from low concentrations of template plasmids $(10 \mathrm{fg} / \mu \mathrm{L})$ by a 2 -consecutive PCR procedure. In this study we will present a simple, fast, and efficient method for accurately assembling multiple DNA fragments into plasmids at a minimum cost based on the homologous recombination capabilities of the common DH5 $\alpha$ strain of E. coli. Extensive recombination experiments were organized to study the relationships between cloning efficiency and four factors (the length of overlapping nucleotides, the number of DNA fragments, concentration of DNA fragments and the size of plasmids). These relationships give valuable practical guide for setting optimum experimental parameters to achieve the desired cloning outcomes.

\section{Materials and methods}

\subsection{Materials:}


PrimeStar ${ }^{\circledR}$ Max DNA Polymerase (Code R045, Takara), KAPA Taq Extra Hot Star polymerase, ready Mix with dye (KAPA BIOSYSTEMS), dNTP, restriction enzymes and DNA markers were purchased from New England Biolabs (NEB). High Efficiency DH 5-alpha chemically competent cells prepared by our lab (Molecular design and synthesis, graduate school of Medicine, Gifu University, Japan) DNA oligonucleotides (Primers) were synthesized by either Integrated DNA Technologies or Life Technologies. Also, DNA Dynamo software, NANODROP 2000c (Thermo scientific), MinElute Gel Extraction Kit (QIAGEN), Lysogeny Broth (LB) agar plates containing the appropriate antibiotic, NucleoBond® Xtra Midiprep Kit (MACHEREY-NAGEL), Incubator, Thermocycler PCR apparatus, gel electrophoresis apparatus and SOC (SuperOptimal broth with Catalite repression) medium ( $2 \%$ tryptone, $0.5 \%$ yeast extract, 10 $\mathrm{mM} \mathrm{NaCl}, 2.5 \mathrm{mM} \mathrm{KCl}, 10 \mathrm{mM} \mathrm{MgCl} 2,10$ $\mathrm{mM} \mathrm{MgSO} 4$, and $20 \mathrm{mM}$ glucose, Invitrogen). 2.2. Amplification of DNA fragments by PCR: Primer pairs for generating DNA fragments with varying overlapping ends by PCR were designed by DNA Dynamo software and provided by Invitrogen and listed at table 1 and amplified by using PrimeStar $^{\circledR}$ Max DNA Polymerase (Code R045, Takara) at the following conditions: $98^{\circ} \mathrm{C}$ for $5 \mathrm{secs}, 98^{\circ} \mathrm{C}$ for $8 \mathrm{secs}, 55^{\circ} \mathrm{C}$ for $10 \mathrm{secs}$ and $72^{\circ} \mathrm{C}(1 \mathrm{~min} / 1 \mathrm{~kb})$ for 17 cycles. Amplification of IRES v2 by using KodFxNeo DNA Polymerase $\left(68^{\circ}, 15 X\right.$, 30sec). Before amplification of PSK-MCS as backbone for Vectors we digested the PSK by single cutter Restriction Enzyme (add $0.5 \mu 1$ to $1 \mu \mathrm{l}$ of PSK, incubated at $37^{\circ} \mathrm{C}$ for 1 hour and digested vector used as template for PCR amplification).

2.3. Construction of plasmids by in vivo recombination of DNA fragments with overlapping ends:
All the plasmids in this study were assembled by E. coli invivo assembly of 3-5 DNA fragments with perfectly matched overlapping ends at different concentrations as shown in table 2\&3. After analysis by gel electrophoresis, DNA fragments from PCR reactions were used directly or after purification or treated by DpnI enzyme for transformation into high efficiency competent E. coli DH5 $\alpha$ cells. The transformation was carried out by thawing the vials of competent E. coli cells on ice for $10 \mathrm{~min}$ followed by addition of mixture of amplified DNA fragments. The mixture was incubated on ice for 30 minutes followed by heat shock by incubation at $42^{\circ} \mathrm{C}$ for 45 seconds. After heat shock, the vials were kept immediately on ice for 2 min followed by adding $200 \mu \mathrm{l}$ of SOC (Super-Optimal broth with Catalite repression) medium (2\% tryptone, $0.5 \%$ yeast extract, 10 $\mathrm{mM} \mathrm{NaCl}, 2.5 \mathrm{mM} \mathrm{KCl}, 10 \mathrm{mM} \mathrm{MgCl} 2,10$ $\mathrm{mM} \mathrm{MgSO} 4$, and $20 \mathrm{mM}$ glucose, Invitrogen). The cells were then incubated for $1 \mathrm{hr}$ at $37^{\circ} \mathrm{C}$ with shaking then selected on Lysogeny Broth (LB) agar plates containing the appropriate antibiotic by incubating at $37^{\circ} \mathrm{C}$ overnight.

\subsection{Colony analysis:}

Developed colonies from each transformation were verified by colony PCR using the appropriate primers by KAPA Taq Extra Hot Star polymerase, ready Mix with dye (KAPABIOSYSTEMS) under the following conditions $95^{\circ} \mathrm{C}$ for $30 \mathrm{secs}, 95^{\circ} \mathrm{C}$ for $10 \mathrm{secs}$, $55^{\circ} \mathrm{C}$ for $10 \mathrm{secs}$ and $72^{\circ} \mathrm{C}(1 \mathrm{~min} / 1 \mathrm{~kb})$ for 34 cycles. The product of PCR is analyzed by gel electrophoresis. The positive clone is cultivated on $\mathrm{LB}$ medium at $37^{\circ} \mathrm{C}$ overnight with shaker then harvest the bacteria by centrifuging at $5000 \mathrm{rpm}$ for 15 minutes then purification of plasmids was carried out using either Fastgene Plasmid miniprep Kit (NIPPON GENETICS) or NucleoBond® Xtra Midiprep Kit (MACHEREY-NAGEL) using high-copy number protocols. The concentration of extracted DNA is measured 
by NANODROP 2000c (Thermoscientific). The structure of Plasmid is validated by enzymatic digestion.

\subsection{Sequence analysis:}

Sequencing was performed using appropriate primers by DNA sequencing Core, Life Science Research Center, Gifu University, Japan according to sequencers specifications.

\section{RESULTS}

\subsection{Cloning efficiency from multiple DNA} fragments with different sizes assembly to construct IRES2KITl, Pmel and Krt14:

Three plasmid constructs of different sizes and number of fragments, IRES2KITl, Pmel and Krt14 with respective $4.2 \mathrm{~Kb}$, (3 fragments), $7.8 \mathrm{~Kb}$ (4 fragments) and $6.25 \mathrm{~Kb}$ (5 fragments) were assembled by invivo recombination of overlapping DNA. The simple requirement for E. coli invivo recombination is the perfectly matched overlapping nucleotides between DNA fragments. Fig 1 showed the gel analysis of DNA fragments after amplification by PCR. The band should be strong and clear without any smear or extra band. After transformation we found 26, $15 \& 13$ colonies at IRES2Kitl, Pmel_Ex_11 and Krt14 respectively as shown in Fig 2\&3. Out of these colonies, we found 50-80 \% were positive after colony PCR, at 4.2 $\mathrm{Kb}$ size was $95 \%, 6.25 \mathrm{~Kb}$ was $90 \%$ and at 7.8 $\mathrm{Kb}$ was $80 \%$ that means that the number of colonies decreased rapidly with the vector size as demonstrated in Fig 3.

3.2. Length of overlapping nucleotides $(O L)$ recombination efficiency relationship from 4fragments assembly to construct $7.8 \mathrm{~kb}$ Pmel:

Multiple fragments assembly experiments using $5 \mathrm{nt}, 10 \mathrm{nt}, 20 \mathrm{nt}$ and $30 \mathrm{nt}$ overLapping nucleotides were conducted to construct the same Pmel. We found after transformation 8 , $14,85 \& 275$ colonies at $5 \mathrm{nt}, 10 \mathrm{nt}, 20 \mathrm{nt}$ and $30 \mathrm{nt}$ overLapping nucleotides respectively as shown in Fig 4 that means the optimum OL is from 25-30nt.

\subsection{Cloning efficiency from multiple DNA} fragments at different concentration:

Multiple fragments assembly experiments using $30 \mathrm{nt}$ overlapping nucleotides at different concentrations were conducted to construct IRES2KITl, Pmel and Krt14. The colony numbers were $10,75 \& 45$ at concentration $25 \mathrm{ng}, 100 \mathrm{ng}$ and $0.5 \mathrm{pmol}$ in total respectively as shown in Fig 5\&6. Out of these colonies we found $85-97 \%$ were positive after colony $\mathrm{PCR}$, at $25 \mathrm{ng}$, percentage of the positive colones was $85 \%, 100 \mathrm{ng}$ was $95 \%$ and at 0.5 pmol in total was $97 \%$ as demonstrated in Fig $6 \& 7$ that means the optimum concentration should be used is $0.5 \mathrm{pmol}$ in total that give the highest efficiency of recombination.

This study is not optimized for high colony numbers but the main goals of developing this protocol were operational simplicity, high cloning accuracy, low costs, and short time for routine cloning were the main goal of developing this protocol. The optimum protocol for invivo Cloning as in shown in Fig. 8 was carried out simply by simply placing a DNA fragment having a homologous sequence (by PCR amplification using appropriate primers as shown in table 1) optimally 25-30 nt OL at the terminus into E. coli. Before amplification the template DNA was digested by single cutter restriction enzyme and used at low concentration for amplification of DNA fragments. This digestion leads to reduction of background colonies of parental plasmid, after Amplification we analyzed the product if the band is clear, it will be used directly without any treatment, but if there is smear or extra band we need gel Purification before transformation, after that we use the fragments at concentration at $0.5 \mathrm{pmol}$ in total and directly transformed into E. coli, following transformation, the developing colonies were screened for positive colony by colony PCR using Appropriate primers as shown in Fig.7. 
3.4. Comparing between conventional method and in vivo assembling:

Vector construction by invivo assembling can be carried out simply by simply placing a DNA fragments having a homologous sequence optimally 25-30 nt OL and at concentration at
$0.5 \mathrm{pmol}$ in total and directly transformed into E. coli, after that the developing colonies were screened for positive clone by colony PCR using appropriate primers and it take totally 3 days. While the conventional method need at least 9 days for finishing the constructs as shown in Fig.9.

Table 1: List of Primers

\begin{tabular}{|c|c|}
\hline Primer & Sequence $(5$ to 3 ) \\
\hline pSK-IRESKitld4_REV_As & TCGCGACGTACGTTCGAACAATTG \\
\hline pSK-IRESKitld4_FWD_As & GGGCCCATATGGCCCACCGGTGGG \\
\hline IRES2-Kitl_FWD_As & TTAAACCAATTGTTCGAACGTACGTCGCGACTCGAGATCCGCCCCTCTCCCTCC \\
\hline IRES2-Kitl_REV_As & AGTTTGTGTCTTCTTCATATTATCATCGTGTTTTTCAAAGGAAAACCACG \\
\hline Kitl-d4_FWD_As & GGCCGGCCCACCGGTGGGCCATATGGGCCCGCGGCCGCTACACATTGATCCTAG \\
\hline Kitl-d4_REV_As & GGCCGGCCCACCGGTGGGCCATATGGGCCCGCGGCCGCTACACATTGATCCTAG \\
\hline pSK-PmelEx11_As_FWD & AAGCTTCGGTCCGCCTAGGGATAACAGG \\
\hline pSK-PmelEx11_As_REV & ACGCGTGATATCATGCATGTTAACATC \\
\hline PmelEx11_5Arm_FWD_As & TTACCCTGTTATCCCTAGGCGGACCGAAGCTTAGCATGGTGCCCAGGAGAGAGCCC \\
\hline PmelEx11_5Arm_REV_As & CTCCGCTTCCGCATGCCCAGACCTGCTGTCCACTGAGGAGC \\
\hline P2ATetON3G_TRE-iCre_FWD & TGGACAGCAGGTCTGGGCATGCGGAAGCGGAGAGGGCAGA \\
\hline P2ATetON3G_TRE-iCre_REV & ATCCACGGTGCCTTGAGCTAGCAGATCTGGCCGGCCCACC \\
\hline PmelEx11_3Arm_FWD_As & GGCCAGATCTGCTAGCTCAAGGCACCGTGGATTTCCTGGG \\
\hline PmelEx11_3Arm_REV_As & GGATCGATGTTAACATGCATGATATCACGCGTGATGGGCC \\
\hline pSK-MCS_FWD_As (k14Ex8) & AGATCTATACCAGGCTCAAG \\
\hline pSK-MCS_REV_As(k14Ex8) & TCTAGAGTCGACCTGCAGGCATGC \\
\hline Krt14Ex8_5Arm_FWD_As & ACGCGTGATATCTGCAGGTCGACTCTAGAGGATCCCATGGCCATTCTCAGTGA \\
\hline Krt14Ex8_3ArmREV_As & ATCGATGTTAACATGCATGATATCACGCGTGAGTTAGTACTCGGGGTGCACAGG \\
\hline
\end{tabular}


Ahmed et al. (2018). BVMJ-35(2): 219-230

Table 2: DNA fragments at $25 \mathrm{ng} \& 100 \mathrm{ng}$

\begin{tabular}{ccccc}
\hline Fragment & Size $(\mathrm{kb})$ & Concentration $(1: 1)$ & $25 \mathrm{ng}$ each & $100 \mathrm{ng}$ each \\
\hline PsK & 2.8 & $95 \mathrm{ng} / \mathrm{uL}$ & $0.26 \mathrm{uL}$ & $1.1 \mathrm{uL}$ \\
IRESv2 & 0.65 & $55 \mathrm{ng} / \mathrm{uL}$ & $0.45 \mathrm{uL}$ & $1.82 \mathrm{uL}$ \\
Kitl-HA & 0.75 & $65 \mathrm{ng} / \mathrm{uL}$ & $0.38 \mathrm{uL}$ & $1.54 \mathrm{uL}$ \\
& Total & & $1.09 \mathrm{uL}$ & $4.46 \mathrm{uL}$ \\
PmelEx11,5' & 1 & $75 \mathrm{ng} / \mathrm{uL}$ & $0.33 \mathrm{uL}$ & $1.33 \mathrm{uL}$ \\
P2A-TetON3G-iCre & 3 & $65 \mathrm{ng} / \mathrm{uL}$ & $0.38 \mathrm{uL}$ & $1.54 \mathrm{uL}$ \\
PmelEx11,3' & 1 & $70 \mathrm{ng} / \mathrm{uL}$ & $0.35 \mathrm{uL}$ & $1.43 \mathrm{uL}$ \\
pSK & 2.8 & $60 \mathrm{ng} / \mathrm{uL}$ & $0.42 \mathrm{uL}$ & $1.67 \mathrm{uL}$ \\
Krt14 Ex8,5' & & & $1.48 \mathrm{uL}$ & $5.97 \mathrm{uL}$ \\
IRES & 1.1 & $195.5 \mathrm{ng} / \mathrm{uL}$ & $0.13 \mathrm{uL}$ & $0.51 \mathrm{uL}$ \\
Kitid4 & 0.65 & $32.7 \mathrm{ng} / \mathrm{uL}$ & $0.76 \mathrm{uL}$ & $3.06 \mathrm{uL}$ \\
Krt14 Ex8,3' & 0.8 & $138.8 \mathrm{ng} / \mathrm{uL}$ & $0.18 \mathrm{uL}$ & $0.72 \mathrm{uL}$ \\
pSK & 0.9 & $162.8 \mathrm{ng} / \mathrm{uL}$ & $0.15 \mathrm{uL}$ & $0.61 \mathrm{uL}$ \\
& 2.8 & $100 \mathrm{ng} / \mathrm{uL}$ & $0.25 \mathrm{uL}$ & $1 \mathrm{uL}$
\end{tabular}

Table 3: DNA fragments at $0.125 \mathrm{pmol}$ for each fragment ( 0.5 pmols in total)

\begin{tabular}{ccccc}
\hline Fragment & Size $(\mathrm{kb})$ & Conc. $(1: 1)$ & Converted conc. & Zmount \\
\hline PsK & 2.8 & $95 \mathrm{ng} / \mathrm{uL}$ & $0.05 \mathrm{pmol} / \mathrm{uL}$ & $2.43 \mathrm{uL}$ \\
IRESv2 & 0.65 & $55 \mathrm{ng} / \mathrm{uL}$ & $013 \mathrm{pmol} / \mathrm{uL}$ & $0.98 \mathrm{uL}$ \\
Kitl-HA & 0.75 & $65 \mathrm{ng} / \mathrm{uL}$ & $0.12 \mathrm{pmol} / \mathrm{uL}$ & $1.02 \mathrm{uL}$ \\
& & & & $4.43 \mathrm{uL}$ \\
PmelEx11,5' & 1 & $75 \mathrm{ng} / \mathrm{uL}$ & $0.11 \mathrm{pmol} / \mathrm{uL}$ & $1.10 \mathrm{uL}$ \\
P2A-TetON3G-iCre & 3 & $65 \mathrm{ng} / \mathrm{uL}$ & $0.03 \mathrm{pmol} / \mathrm{uL}$ & $3.81 \mathrm{uL}$ \\
PmelEx11,3' & 1 & $70 \mathrm{ng} / \mathrm{uL}$ & $0.11 \mathrm{pmol} / \mathrm{uL}$ & $1.18 \mathrm{uL}$ \\
pSK & 2.8 & $60 \mathrm{ng} / \mathrm{uL}$ & $0.03 \mathrm{pmol} / \mathrm{uL}$ & $3.85 \mathrm{uL}$ \\
Krt14 Ex8,5' & & & $5.97 \mathrm{uL}$ \\
IRES & 1.1 & $195.5 \mathrm{ng} / \mathrm{uL}$ & $0.27 \mathrm{pmol} / \mathrm{uL}$ & $0.46 \mathrm{uL}$ \\
Kitid4 & 0.65 & $32.7 \mathrm{ng} / \mathrm{uL}$ & $0076 \mathrm{pmol} / \mathrm{uL}$ & $1.64 \mathrm{uL}$ \\
Krt14 Ex8,3' & 0.8 & $138.8 \mathrm{ng} / \mathrm{uL}$ & $0.26 \mathrm{pmol} / \mathrm{uL}$ & $0.48 \mathrm{uL}$ \\
pSK & 0.9 & $162.8 \mathrm{ng} / \mathrm{uL}$ & $0.27 \mathrm{pmol} / \mathrm{uL}$ & $0.46 \mathrm{uL}$ \\
& 2.8 & $100 \mathrm{ng} / \mathrm{uL}$ & $0.05 \mathrm{pmol} / \mathrm{uL}$ & $2.31 \mathrm{uL}$ \\
& & & & $5.35 \mathrm{uL}$ \\
\hline
\end{tabular}



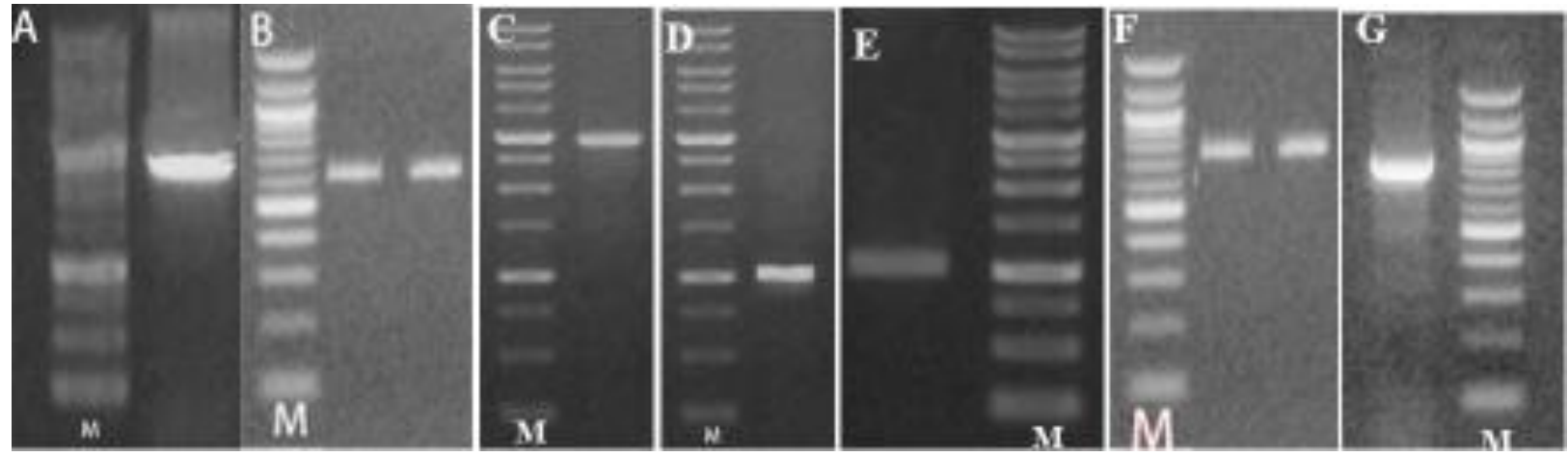

Fig.1. Gel analysis of DNA fragments after Amplification by PCR, A) Amplification of PSK by Primestar Max DNA Polymerase, target size $2.8 \mathrm{~Kb}$. B) Amplification of IRES2 by KodFxNeo DNA Polymerase, target size $0.65 \mathrm{~Kb}$ at first lane \& KITl by Primestar Max DNA Polymerase, target size $0.75 \mathrm{~Kb}$ at second lane. C) Amplification of P2A-TetON3G-iCre by Primestar Max DNA Polymerase, target size $3 \mathrm{~Kb}$. D) Amplification of Pmel EX_11 5Arm by Primestar Max DNA Polymerase, target size $1 \mathrm{~Kb}$. E) Amplification of Krt14 5Arm by Primestar Max DNA Polymerase, target size 1.1 Kb. F) Amplification of IRES2 by KodFxNeo DNA Polymerase, target size $0.65 \mathrm{~Kb}$ at first lane \& Krt14 Arm by Primestar Max DNA Polymerase, target size $0.9 \mathrm{~Kb}$ at second lane. G) Amplification of KitlHA by Primestar Max DNA Polymerase, target size $0.8 \mathrm{~Kb}$. (M: 1KB DNA Ladder (A, C, D, E) \& 100bp DNA Ladder (B, F, G).

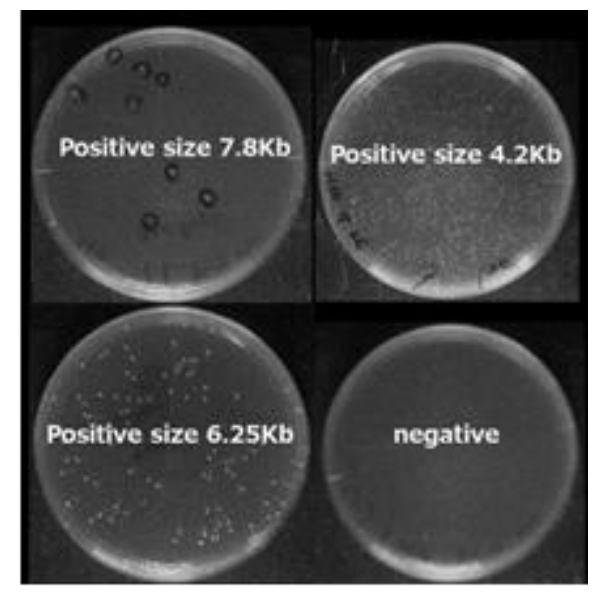

Fig.2. Colony Numbers after transformation of Vectors of different sizes.

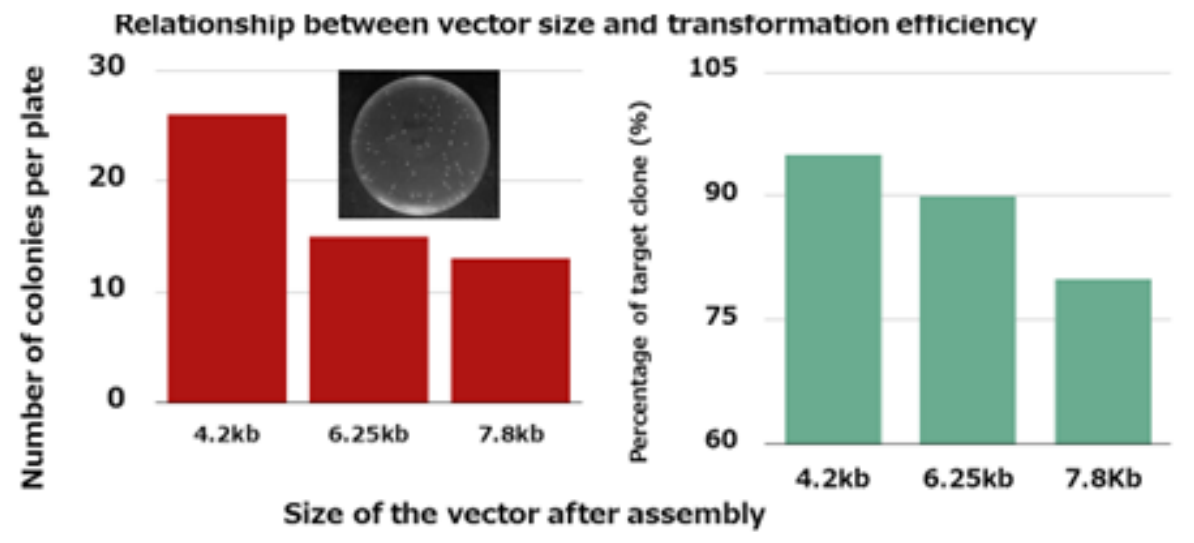

Fig.3. Relationship between vector size and transformation efficiency. 
Ahmed et al. (2018). BVMJ-35(2): 219-230
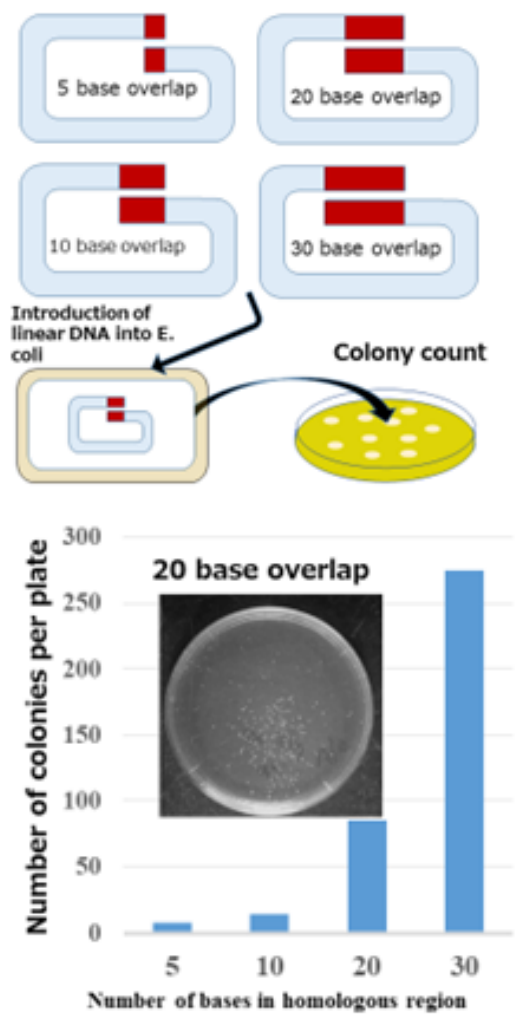

Fig.4. Relationship between overlapping Nucleotides (OL) and transformation efficiency.

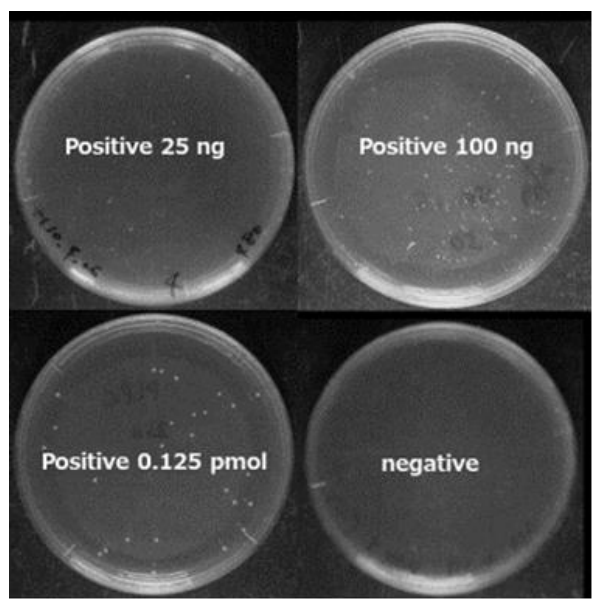

Fig.5. Colony Numbers after transformation of Vectors of DNA fragment at different concentrations.

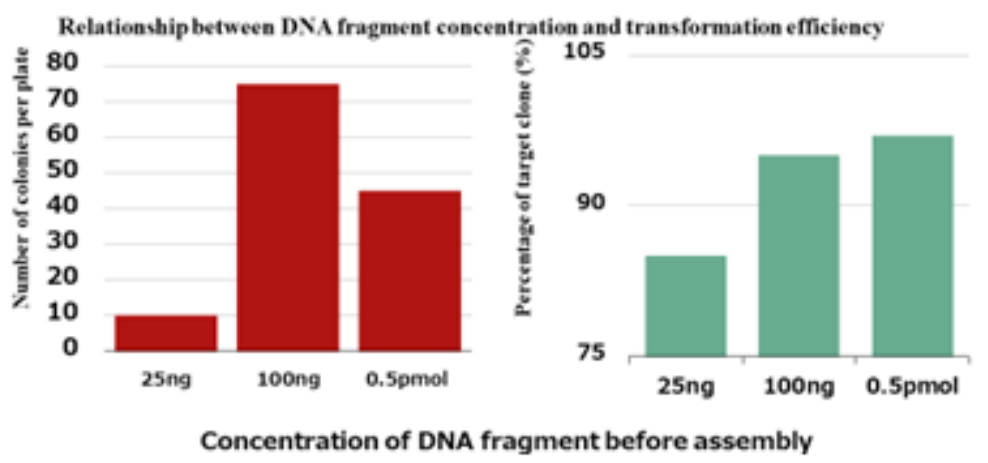

Fig.6. Relationship between DNA fragment concentration and transformation efficiency. 


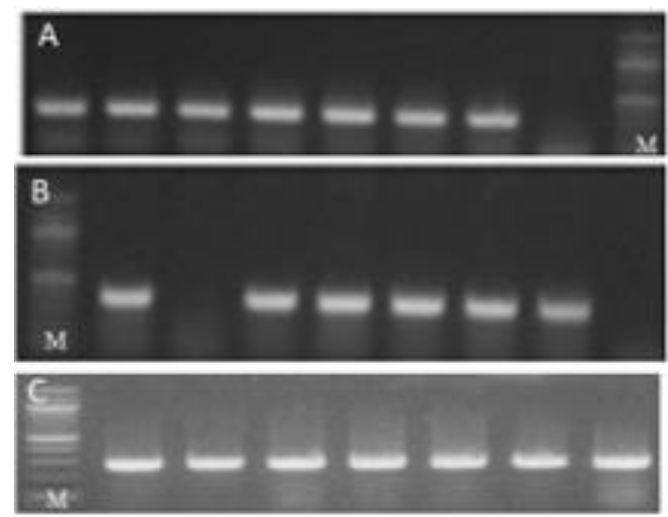

Fig.7. Colony PCR for developed Colonies Concentration and transformation efficiency A) Colony PCR at concentration of $100 \mathrm{ng} \mathrm{B)} \mathrm{Colony} \mathrm{PCR} \mathrm{at} \mathrm{concentration} \mathrm{of} 25 \mathrm{ng}$. C) Colony PCR at concentration of 0.5 in total pmol (M: DNA Ladder).

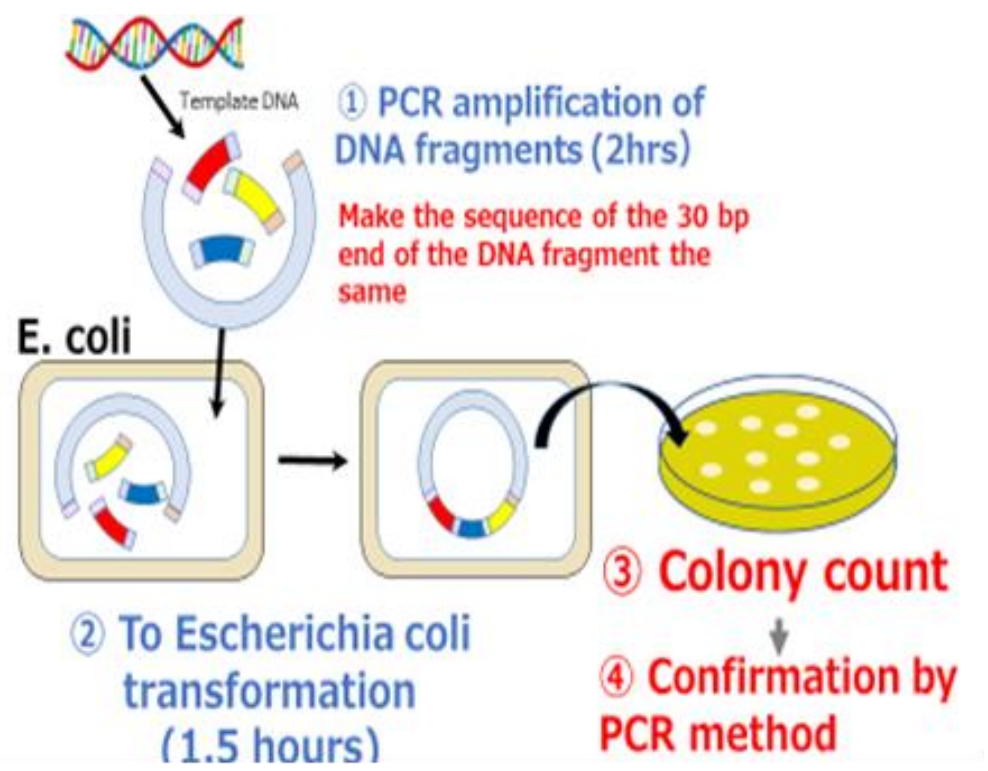

Fig.8. Summary for invivo assembling of DNA comparing with Conventional method.

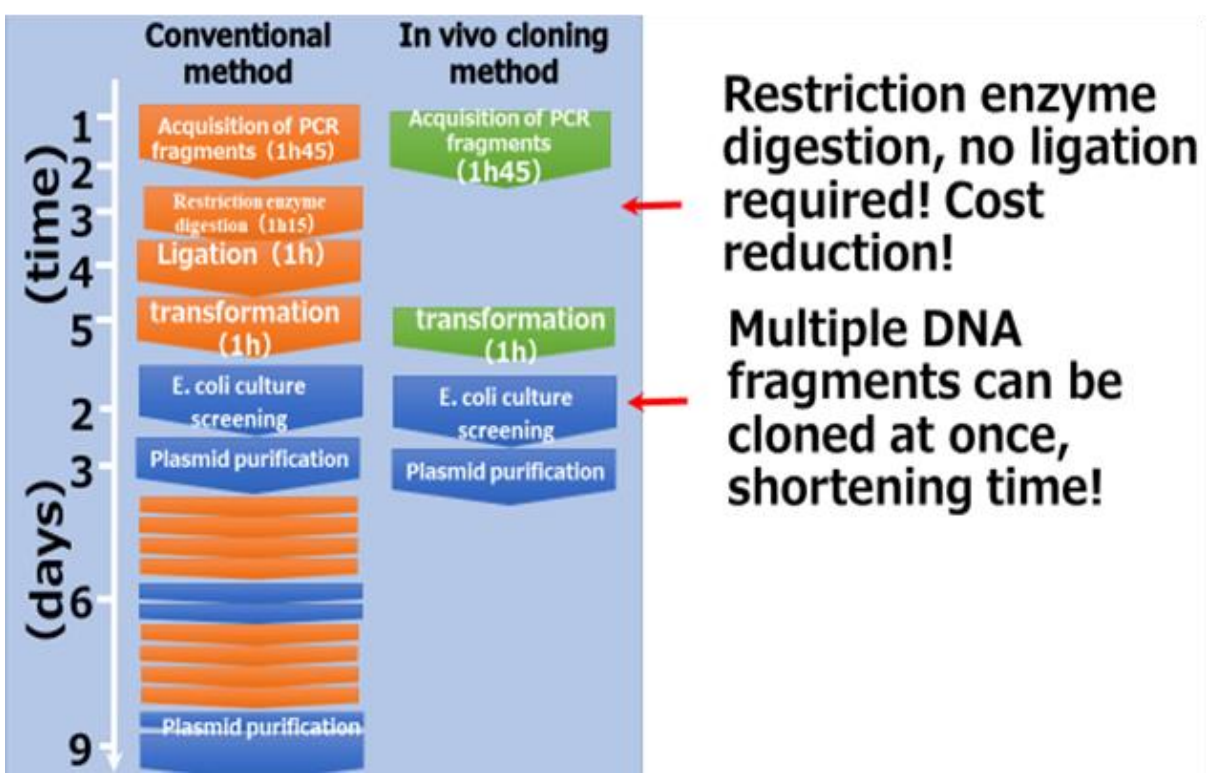

Fig.9. Comparison between Conventional method \& Invivo cloning method for DNA cloning. 


\section{DISCUSSION}

The basic principle of E. coli invivo recombination was first seen in 1985 (Watt et al., 1985). However, its application in cloning has been limited by a lack of understanding of the factors affecting recombination efficiency in E. coli. The goal of this study was to find a simple, lowering cost, fast and efficient cloning method for broad applications based on E. coli invivo recombination.

To eliminate the background colnies, after amplification of fragments, the DNA fragments treated with DpnI enzyme (Jacobus and Gross, 2015 \& Kostylev et al., 2015; Garcia-Nafria et al., 2016 and Huang et al., 2017), or performing 2 consecutive PCR amplification reactions which could easily bring the concentration of template plasmids below a certain level (Huang et al., 2017). In our procedure the template DNA was digested by single cutter restriction enzyme before amplification and also very low concentration of the original template plasmid was used. Our procedure is safer than that reported by Huang et al. (2017) by doing 2 successive PCR for amplification because the 2 successive PCR increase the mutation rate of DNA.

Like (Huang et al., 2017), the number of colonies decreased with increase the number of DNA fragments and the larger DNA fragments are amplified less efficiently than smaller ones under the same PCR conditions in a single tube reaction setting. We also found that even similar DNA sizes may have different PCR amplification efficiencies.

The present study, Garcia-Nafria et al. (2016) and Faqing et al. (2017) suggested that PCR amplification of multiple DNA fragments with overlapping ends in a single-tube reaction may be difficult to accomplish in routine experiments. Preparation of individual DNA fragments by separate PCR reactions as reported in the current study is therefore highly recommended.

According to Watt et al. (1985), invivo recombination in E. coli increases rapidly with OL from 20 to 74 nt that increases the cost of the primers in addition to chance of mispriming and undesired DNA fragments. While, Jacobus and Gross (2015); Kostylev et al. (2015) and Garcia-Nafria et al. (2016) use 30-50 nt OL to produce a reasonable number of colonies. In this study, the optimum OL is from 25-30nt OL that give balance between the primer cost, mispriming, and invivo assembly efficiency that was in agreement with (Huang et al., 2017).

The conventional restriction digestion and ligation (Lobban and Kaiser 1973 \& Cohen et al., 2017) need at least 9 days for completing the construction of vector in addition to the highly cost, while the invitro assembling of DNA (Aslanidis \&Jong, 1990; Geu-Flares et al., 2007; Zhu et al. 2007 and Gibson et al., 2009) need highly cost reagent for recombination before transformation.

\section{REFERENCES}

Aslanidis, C., de Jong and P. J. (1990): Ligation-independent cloning of PCR products (LIC-PCR). Nucleic Acids Res. 18(20):6069-6074.

Bubeck, P., Winkler, M. and Bautsch, W. (1993): Rapid cloning by homologous recombination in vivo. Nucleic Acids Res. 21(15):3601-3602.

Cao, P., Wang, L., Zhou, G., Wang, Y. and Chen Y. (2014): Rapid assembly of multiple DNA fragments through direct transformation of PCR products into E. coli and Lactobacillus. Plasmid. 76:4046. 
Cohen, S. N., Chang, A. C., Boyer, H. W. and Helling, R. B. (1973): Construction of biologically functional bacterial plasmids in vitro. Proc Natl Acad Sci U S A. 70(11):3240-3244.

Dutra, B. E., Sutera, V. A. and Lovett, S. T. (2007):

RecA-independent recombination is efficient but limited by exonucleases. Proc Natl Acad Sci U S A. 104(1):216-221.

Garcia-Nafria, J., Watson, J. F. and Greger, I. H. (2016): IVA cloning: A single-tube universal cloning system exploiting bacterial In Vivo Assembly. Sci Rep. 6:27459

Geu-Flores, F., Nour-Eldin, H. H., Nielsen, M. T. and Halkier, B. A. (2007): USER fusion: a rapid and efficient method for simultaneous fusion and cloning of multiple PCR products. Nucleic Acids Res. 35(7):e55.

Gibson, D. G., Benders, G.A., AndrewsPfannkoch, C., Denisova E. A., BadenTillson, H. and Zaveri, J, et al. (2008): Complete chemical synthesis, assembly, and cloning of a Mycoplasma genitalium genome. Science; 319(5867):1215-1220.

Gibson, D. G., Young, L., Chuang, R. Y., Venter, J. C., Hutchison, C.A. and Smith, H. O. (2009): Enzymatic assembly of DNA molecules up to several hundred kilobases. Nat Methods.; 6(5):343-345.

Huang, F., Spangler, J. R. and Huang, A. Y. (2017): In vivo cloning of up to $16 \mathrm{~kb}$ plasmids in E. coli is as simple as PCR, PLOS

ONE,

10.1371/journal.pone.0183974.

Jacobus, A. P. and Gross, J. (2015): Optimal cloning of PCR fragments by homologous recombination in

Escherichia coli. PLoS One. 10(3):e0119221.

Joska, T. M., Mashruwala, A., Boyd, J. M. and Belden, W. J. A. (2014): universal cloning method based on yeast homologous recombination that is simple, efficient, and versatile. $\mathrm{J}$ Microbiol Methods. 100:46-51.

Kostylev, M., Otwell, A. E., Richardson, R. E. and Suzuki, Y. (2015): Cloning Should Be Simple: Escherichia coli DH5alphaMediated Assembly of Multiple DNA Fragments with Short End Homologies. PLoS One. 10 (9):e0137466.

Li, C., Wen, A., Shen, B., Lu, J., Huang, Y. and Chang, Y. (2011): a highly simplified, purification-free, sequence- and ligation-independent PCR cloning method. BMC Biotechnol. 11:92.

Li, M. Z. and Elledge, S. J. (2007): Harnessing homologous recombination in vitro to generate recombinant DNA via SLIC. Nat Methods. 4(3):251-256.

Lobban, P. E. and Kaiser A. D. (1973): Enzymatic end-to end joining of DNA molecules. J Mol Biol. 78(3):453- 471.

Lovett, S. T., Hurley, R. L., Sutera, V. A., Aubuchon, R. H. and Lebedeva, M. A. (2002): Crossing over between regions of limited homology in Escherichia coli. RecA-dependent and RecAindependent pathways. Genetics. 160(3):851-859.

Ma, H., Kunes S, Schatz PJ, Botstein D. 1987; Plasmid construction by homologous recombination in yeast. Gene. 58(23):201-216.

Muyrers, J. P., Zhang, Y. and Stewart, A. F. (2000): ET-cloning: think 
recombination first. Genet Eng $(\mathrm{N} \mathrm{Y})$. 22:77- 98 .

Oldenburg, K. R., VO, K. T., Michaelis, S. and Paddon, C. (1997): Recombinationmediated PCR-directed plasmid construction in vivo in yeast. Nucleic Acids Res. 25(2):451-452

Oliner, J. D., Kinzler, K. W. and Vogelstein, B. (1993): In vivo cloning of PCR products in E. coli. Nucleic Acids Res. 21(22):5192-7.

Shao, Z. and Zhao, H. (2014): Manipulating natural product biosynthetic pathways via DNA assembler. Curr Protoc Chem Biol.; 6(2):65-100.

Trehan, A., Kielbus, M., Czapinski, J., Stepulak, A., Huhtaniemi, I. and Rivero-Muller, A. (2016): REPLACRmutagenesis, a one-step method for sitedirected mutagenesis by recombineering. Sci Rep. 6:19121.

Van Leeuwen, J., Andrews, B., Boone, C. and Tan, G. (2015): Rapid and Efficient Plasmid Construction by Homologous Recombination in Yeast. Cold Spring Harb Protoc. 2015(9):pdb prot085100.

Watt, V.M., Ingles, C. J., Urdea, M. S. and Rutter, W. J. 1985; Homology requirements for recombination in Escherichia coli. Proc Natl Acad Sci U S A. 82(14):4768-4772.

Zhang, Y., Muyrers, J.P., Testa, G. and Stewart, A. F. (2000): DNA cloning by homologous recombination in Escherichia coli. Nat Biotechnol. 18(12):1314-1317.

Zhu, B., Cai, G., Hall, E. O. and Freeman, G J. (2007): In-fusion assembly: seamless engineering of multidomain fusion proteins, modular vectors, and mutations. Biotechniques. 43(3):354359. 